\title{
Antifungal efficacy of leaf, flower and root of Aerva lanata (Linn.) against selected fungal pathogens
}

\author{
Ramalingam Vidhya ${ }^{1,2}$, Rajangam Udayakumar ${ }^{1 *}$ \\ ${ }^{1}$ Department of Biochemistry, Government Arts College (Autonomous), Kumbakonam, Tamilnadu, India. \\ ${ }^{2}$ Department of Biochemistry, Dharmapuram Gnanambigai Government Arts College for Women, \\ Mayiladuthurai, Tamilnadu, India.
}

\begin{abstract}
Background: The aim of this study is to determine the antifungal activity of different parts like leaf, flower and root extracts of Aerva lanata (L.).

Material and Methods: The antifungal activity of different solvents like acetone, aqueous, benzene and ethylacetate extracts of A. lanata against Candida parapsilosis, Aspergillus flavus, Trichosporon asahii and Mucor indicus was studied by agar well diffusion method.

Results: Benzene extract of leaf of $A$. lanata showed maximum zone of inhibition against Aspergillus flavus. The benzene extract of flower showed antifungal activity against Trichosporon asahii. The acetone extract of root showed antifungal activity against Candida parapsilosis, Aspergillus flavus, Trichosporon asahii and Mucor indicus.

Conclusion: The best antifungal activity was observed in all solvent extracts of root of $A$. lanata against selected fungal species such as Candida parapsilosis, Aspergillus flavus, Trichosporon asahii and Mucor indicus, when compared with leaf and flower extracts. In future, there is in need of study to isolate and purify the active phytocompounds, which possess antifungal activity against above mentioned fungal species and it may be useful in the treatment of fungal diseases.
\end{abstract}

Key words: Aerva lanata, antifungal activity, leaf, flower, root.

\section{Introduction}

Ifectious diseases are caused by fungi, bacteria, viruses and parasites. These are the major threat to public health despite tremendous growth in human chemotherapeutic medicine. Their impact is particularly great in developing countries because of the unavailability of medicines and the emergence of widespread drug resistance (1). The spread of drug resistant pathogens is one of the most serious threats to successful treatment of microbial diseases. The essential oils and phytocompounds of plant extracts such as alkaloids, flavonoids, phenolics, tannins and steroids have evoked interest as sources of natural

*Corresponding Author: Dr. R. Udayakumar, Department of Biochemistry, Government Arts College (Autonomous), Kumbakonam, Tamilnadu, India E-mail: udayabiochem@gmail.com Received: Jun 25, 2016 Accepted: Dec 05, 2016 Published Online: Feb 15, 2017. products. The screening of antimicrobial activity of medicinal plants is an alternative remedies for the treatment of many infectious diseases (2).

The majority of the world population depends on traditional medicine for primary health care. Medicinal and aromatic plants which are widely used as medicine constitute a major source of natural organic compounds. Plants have limitless ability to synthesize aromatic substances and most of which are phenols or their oxygen derivatives.
This is an Open Access article distributed under the terms of the Creative Commons Attribution Non-Commercial License (http://creativecommons.org/licenses/bync/4.0/) which permits unrestricted non-commercial use, distribution, and reproduction in any medium, provided the original work is properly cited. 
The phytocompounds have been shown to possess antibacterial, antifungal, antiviral, insecticidal and antioxidant properties (3).

Nowadays, multiple drug resistance has developed due to the indiscriminate use of commercial antimicrobial drugs commonly used in the treatment of infectious diseases (4). In addition to this problem, antibiotics are sometimes associated with adverse effects on the host, including hypersensitivity, immune suppression and allergic reactions (5). More side effects were observed in patients using allopathic drugs for treating diseases. So the scientists focused their research on to find new antimicrobial agents from medicinal plants. Plant based drugs are cheap and very less side effects. Therefore, there is a need to develop alternative antimicrobial drugs for the treatment of infectious diseases from medicinal plants (6). Several screening studies have been carried out in different parts of the world. There are several reports on the antimicrobial activity of different herbal extracts of different regions of the world (7).

Herbal plants have become increasingly popular and their use is widespread. Clear-cut proof of their efficacy on microorganisms inducing pathogenesis is yet to be explored. Various medicinal plants have been used for years in daily life to treat disease all over the world. Higher plants, as sources of medicinal compounds, have continued to play a dominant role in the maintenance of human health since ancient times (8). Over $50 \%$ of all modern clinical drugs are of natural product origin (9) and natural products play an important role in drug development programs in the pharmaceutical industry (10). It has been suggested that aqueous and ethanolic extracts from plants used in allopathic medicine are potential sources of antiviral, antitumoral and antimicrobial agents (11).

Aerva lanata (L.) belongs to Amaranthaceae family is known as "Chaya" in Hindi and "Bhadram" in Sanskrit and "Palai" in Tamil (12). A. lanata has been used as diuretic, antihelmintic, antidiabetic, expectorant and hepatoprotective drugs (13). Antimicrobial and cytotoxicity activities (14), diuretic activity (15) urolithiasis (16) and anti-inflammatory activity (17) of $A$. lanata were reported. It has been reported that canthin-6one and $\beta$-carboline alkaloids were isolated from leaves of A. lanata (18). The antidiabetic activity of A. lanata was reported $(19,20)$ and the studies have shown that diabetic patients are susceptible to infections (21). Diabetic patients are at great risk of bacterial and fungal infections and they have an increased susceptibility to develop skin and soft tissue infections. In this study, the antifungal activities of various solvent extracts of leaf, flower, and root of A. lanata were screened against selected fungal species such as Candida parapsilosis, Aspergillus flavus,
Trichosporon asahii and Mucor indicus.

\section{Methods and materials \\ Collection of plant material}

The medicinal plant A. lanata was collected from Mayiladuthurai, Nagapattinam District, Tamilnadu, India during the month of November 2013 and authenticated by the Botanist Dr. S. John Britto, Director, Rabinet Herbarium and Centre for Molecular Systematics, St. Joseph's College, Tiruchirappalli-620 002, Tamilnadu, India.

\section{Preparation of plant extracts}

The root, flower and leaves were separated from the collected plant and cleaned. The separated parts were dried under shade and then ground well into powder. $30 \mathrm{~g}$ powder of root, flower and leaves were taken separately in different conical flasks and labeled. $500 \mathrm{ml}$ of solvents like acetone, benzene and ethyl acetate were added in each conical flask separately shaken well and plugged with cotton and then kept at room temperature for 3 days. On the fourth day, the contents were shaken well and filtered through muslin cloth and then filtered again using Whatmann no. 1 filter paper. Then the filtrates were concentrated through hydro-distillation process. The extracts were dried until a constant weight of each was obtained (24). $30 \mathrm{~g}$ powder of root, flower and leaves were soaked separately in distilled water for 12 to 16 hours and boiled and then it was filtered through muslin cloth and then Whatmann no. 1 filter paper. The aqueous extracts were concentrated and made the final volume to one-fifth of the original volume (25). The extracts were stored in air tight containers at $4{ }^{\circ} \mathrm{C}$ until the time of use.

\section{Fungal strains}

The fungal strains Candida parapsilosis, Aspergillus flavus, Trichosporon asahii and Mucor indicus were used in this study and the fungal cultures were collected from Microbiology Laboratory, Doctors Diagnostic Centre, Tiruchirappalli, Tamilnadu, India and where the fungal strains were isolated from blood smear and urine cultures of urinary tract infected (UTIs) patients. The fungal cultures were maintained in Rose Bengal Agar slants at 4 ${ }^{\circ} \mathrm{C}$. For this study, the fungi were sub-cultured in broth and incubated at $37^{\circ} \mathrm{C}$ for 72 hours before use.

\section{Preparation of medium}

The composition of Rose Bengal Agar media is papaic digest of soya bean meal - $5 \mathrm{~g}$; Dextrose - $10 \mathrm{~g}$; Mono potassium phosphate $-1 \mathrm{~g}$; Magnesium sulphate - $0.5 \mathrm{~g}$; Rose Bengal - $0.05 \mathrm{~g}$ and Agar - $15 \mathrm{~g} .31 .55 \mathrm{~g}$ of Rose Bengal Agar in $1000 \mathrm{ml}$ of distilled water and boiled to dissolve the medium completely then sterilized by 
autoclaving at $15 \mathrm{lbs}$ pressure $\left(121^{\circ} \mathrm{C}\right)$ for 15 minutes, and then cooled to $45^{\circ} \mathrm{C}$ (pH 7.2 \pm 0.2 ). It is mixed throughly and poured into sterile petri plates.

\section{Determination of antifungal activity by agar well diffusion method}

Rose Bengal Agar (RBA) plates were swabbed using sterile cotton swabs with $8 \mathrm{hr}$ old broth culture of the respective fungi such as Candida parapsilosis, Aspergillus flavus, Trichosporon asahii and Mucor indicus. A sterile cork borer was used to make wells. In this study, $0.6 \mathrm{~g}$ of dried extracts was dissolved in $2 \mathrm{ml}$ of DMSO and used as sample. In this study the DMSO (inert organic solvent) and amphotericin B (10 $\mu \mathrm{g}$, antifungal drug) were used as negative control and positive control, respectively. The plant samples were used at different concentrations like 25 $\mu \mathrm{l}$ (7.5 mg), $50 \mu \mathrm{l}(15 \mathrm{mg}), 75 \mu \mathrm{l}(22.5 \mathrm{mg})$ and $100 \mu \mathrm{l}$ (30 $\mathrm{mg}$ ). The plant extract was added into each well using sterilized micropipette and allowed the extracts for diffusion at room temperature for $2 \mathrm{hrs}$. The plates were incubated at $28{ }^{\circ} \mathrm{C}$ for $72 \mathrm{hrs}$. Diameter of the inhibition zones was measured (26).

\section{Statistical Analysis}

All the results were subjected to statistical analysis and the results are expressed as mean \pm standard deviation of three replicates.

\section{Results}

In this study, the pharmacological evaluation of antifungal activities of four different solvent extracts of leaf, flower and root of A. lanata was carried out using agar well diffusion method and the results are represented in Tables 1,2 and 3. It is an important to investigate scientifically plants that have been used in traditional medicines to determine potential sources of novel antimicrobial compounds.

Antifungal activity of different solvent extracts of leaf of A. lanata against selected fungal species such as Candida parasilosis, Aspergillus flavus, Trichosporon asahii and Mucor indicus was determined. Aqueous and ethyl acetate extracts of leaves showed minimum zone inhibition against Aspergillus flavus, but no antifungal activity against the other three selected microorganisms. Benzene extract of leaf showed maximum activity against Aspergillus flavus, at the concentration of $22.5 \mathrm{mg}$ $(16 \pm 0.35 \mathrm{~mm})$ and $30 \mathrm{mg}(18 \pm 0.43 \mathrm{~mm})$. Acetone extract of leaves showed less activity against Trichosporan asahii when compared with standard drug Amphotericin B (Table1).

Table 2 represented the results of antifungal activities of different solvent extracts of flower of A. lanata against selected fungal species. Aqueous and acetone extracts of flower of A. lanata showed no zone of inhibition against Candida parapsilosis, Aspergillus flavus, Trichosporon asahii and Mucor indicus. Benzene and ethylacetate extracts of flower of $A$. lanata exhibit maximum activity against Trichosporon asahii as $18 \pm 0.4 \mathrm{~mm}$ and $15 \pm 0.45$ $\mathrm{mm}$, respectively at the concentration of $30 \mathrm{mg}$. Ethyl acetate extract of flower also exhibits better activity against Mucor indicus $(14 \pm 0.63 \mathrm{~mm})$.

Table 3 showed that the results of antifungal activity of different solvents extracts of root of A. lanata. All solvent extracts of root of $A$. lanata showed maximum inhibition against tested fungal species. The acetone extract showed antifungal activity against Candida parasilosis $(20 \pm 0.48$ $\mathrm{mm})$, Aspergillus flavus (18 $\pm 0.55 \mathrm{~mm})$, Trichosporon asahii $(18 \pm 0.58 \mathrm{~mm})$, and Mucor indicus $(24 \pm 0.60 \mathrm{~mm})$. Whereas ethyl acetate extract showed higher degree of inhibition against selected fungal species, when compared to aqueous and benzene extracts of root.

\section{Discussion}

Fungal infections are representing a critical problem to health and they are one of the main causes of morbidity and mortality worldwide (27). Human infections, particularly those involving in the skin and mucosal surfaces, constitute a serious problem, especially in tropical and subtropical developing countries (28). In recent years, fungal infections range from superficial to deeply invasive or disseminated, and have increased dramatically in humans.

In recent years, the medicinal plants researches have attracted a lot of attentions globally. A large body of evidence has accumulated to demonstrate the promising potential of medicinal plants used in various traditional, complementary and alternate systems of treatment of human diseases. Plants are rich in variety of secondary metabolites such as tannins, terpenoids, alkaloids, flavonoids, glycosides and phenolic compounds etc., which have been found in vitro antimicrobial properties (30). Similarly, the antifungal properties of petroleum 
ether, chloroform and methanol extracts of Hybanthus enneaspermus were reported against Aspergillus flavus, Aspergillus fumigatus, Candida albicans and Candida tropicalis by well diffusion method (31). Further, the antifungal activity of methanol extract of leaf of Euphorbia hirta against C. albicans was reported (32). The antifungal activity of different solvent extracts of leaf and flower of Withania somnifera was reported (33). The antifungal activity of methanol and water extracts of Aerva lanata showed inhibition zones against selected fungal species (34).

Mathur et al. (35) reported that hydro-alcohol extract of Valeriana jatamansi, Coleus barbatus, Berberis aristata, Asparagus racemosus, Andrographis paniculata, Achyranthes aspera, Tinospora cordifolia and Plantago depressa showed antifungal activity against Aspergillus niger and Candida albicans. Similarly, Sule et al. (36) evaluated that the antifungal activity of Senna alata (L.) and in that study the crude leaf extract exhibited antifungal activity against Microsporum canis, Trichophyton jirrucosum, Trichophyton mentagrophytes and Epidermophyton jlorrcosum. Abera et al. (37) reported that the antifungal potential of aqueous and ethanol extracts of eight different plant species against Colletotrichum kahawae. Bohra and Purohit (38) reported that the antifungal activities of aqueous extracts of Azadirachta indica against Aspergillus flavus (39). Similarly, Taskeen-Un-Nisa et al. (40) reported that the antimycotic activity of onion (Allium cepa L.), garlic (Allium sativum L.) and mint (Mentha arvensis L.) extracts against some selected pathogenic fungi.

The results of the present study showed that the antifungal activity of leaf, flower and root extracts of A. lanata. Similarly, Manohari and Prasanna (41) reported that the antifungal activity of aqueous and ethanolic extract of leaf of A. lanata against Aspergillus niger and Trichoderma viride. The ethyl acetate and methanol extracts of whole plant of A. lanata showed antifungal activities against Aspergillus fumigatus, Aspergillus niger, Candida albicans, Hensinela californica and Rhizopus oligosporum (42). Amutha Kuppusamy (43) was also screened the antimicrobial activity of methanolic extract of A. lanata against Candida tropicalis. Earlier report showed that the ethyl acetate and methanol extracts of $A$. lanata have antimicrobial properties (42). Flavonoids, triterpenes and tannins are present in A. lanata and it may be responsible for antimicrobial properties (44). The methanol extract of A. lanata showed that the presence of alkaloids, tannins, saponins, flavonoids, carbohydrates, glycosides, phenols, steroids, phlobatannins, cardiac glycosides, proteins and resins (45). Flavonoids are hydroxylated phenolic substance known to be synthesized by plants in response to microbial infection and it should not be surprising that they have been found in vitro to be effective antimicrobial substances against a wide array of microorganisms (46). Coumarins are produced in carrots in response to fungal infection, which could be attributed to its antimicrobial activity (47). Antimicrobial property of saponins is due to its ability to cause leakage of proteins and certain enzymes from the cell (48). In the present study, the maximum level of antifungal activity was observed in root extracts of A. lanata against Candida parapsilosis, Aspergillus flavus, Trichosporon asahii and Mucor indicus. Similarly, the root extract of Hypochaeris radicata showed maximum antimicrobial activity when compared to other parts of plant (49). This may be due to the presence of flavonoids and phenolic compounds in the roots of plant (50). Flavonoids and phenolic compounds may have the capacity to rupture the cytoplasmic membrane of the fungal cells and damage the intracellular compounds (51) or they may interact with lipid bilayer or inhibit the protein and nucleic acid synthesis in fungal cell (52).

\section{Conclusion}

In this study, the antifungal activities of different solvent extracts of leaf, flower and root of A. lanata were confirmed against selected fungal species such as Candida parapsilosis, Aspergillus flavus, Trichosporon asahii and Mucor indicus. The root extracts of A. lanata were showed maximum activities against selected fungal species. So the root extracts were showed broad spectrum antifungal activity when compared to flower and leaf extracts against Aspergillus flavus, Trichosporon asahii and Mucor indicus. Antimicrobial properties of herbs are due to the presence of secondary metabolites like alkaloids, flavanoids, tannins, terpenoids, phenols, saponins and steroids. So, the further study is needed to find out the phytocompounds, which are responsible for antifungal activities.

Ethics Committee Approval: N.A. Informed Consent: N.A. 
Peer-review: Externally peer-reviewed.

Conflict of Interest: No conflict of interest was declared by the author.

Financial Disclosure: The author declared that this study has received no financial support.

\section{References}

1. Okeke IN, Laxminarayan R, Bhutta ZA, Duse AG, Jenkins P, O'Brien TF, et al. Antimicrobial Resistance in developing countries. Part 1: recent trends and current status. Lancet Infect Dis 2005; 5: 481-493.

2. Tepe B, Daferera D, Sokmen M, Polissiou M, Sokmen A. In vitro antimicrobial and antioxidant activities of the essential oils and various extracts of Thymus eigii. M. Zoharyet P. H. Davis. J Agric Food Chem 2004; 52: 1132-1137.

3. Kordali S, Kotan R, Mavi A, Cakir A, Ala A, Yildirim A. Determination of the chemical composition and antioxidant activity of the essential oil of Artemisia dracunculus and of the antifungal and antibacterial activities of Turkish Artemisia absinthium, Artemisia dracunculus, Artemisia santonicum, and Artemisia spicigera essential oils. J Agric Food Chem. 2005; 53: 9452-9458.

4. Service RF. Antibiotics that resist resistance. Science 1995; 270: 724-727.

5. Ahmad I, Mehmood Z, Mohammad F. Screening of some Indian medicinal plants for their antimicrobial properties. $J$ Ethnopharm 1998; 62: 183-193.

6. Cordell GA. Biodiversity and drug discovery a symbiotic relationship. Phytochem 2000; 55: 463-480.

7. De Boer HJ, Kool A, Broberg A. Mziray WR, Hedberg I, Levenfors JJ. Antifungal and antibacterial activity of some herbal remedies from Tanzania. J Ethnopharm 2005; 96: 461469.

8. Farombi EO. African indigenous plants with chemotherapeutic potentials and biotechnological approach to the production of bioactive prophylactic agents. Afr $J$ Biotechnol 2003; 2: 662-671.

9. Stuffness M, Douros J. Current status of the NCI plant and animal product Program. J Nat Prod. 1982; 4: 51-14.

10. Baker JT, Borris RP, Carte B, Cordell GA, Soejarto DD, Cragg GM, et al. Natural product drug discovery and development: New perspective on international collaboration. $J$ Nat Prod 1995; 58: 1325-1357.

11. Vlietinck AJ, van Hoof L, Totte J, Lasure A, Vanden Berghe D, Rwangabo PC et al. Screening of hundred Rwandese medicinal plants for antimicrobial and antiviral properties. $J$ Ethnopharmacol 1995; 46: 31-47.

12. Aiyer $\mathrm{KN}$, Kolammal $\mathrm{M}$, editors. Pharmacognosy of Ayurvedic drugs, Series1. 1st ed. Trivendram: The Central Research Institute, 1963; p. 6.

13. Kiritikar KR, Basu BD. Indian Medicinal Plants: International book distributors. Dehradun, India. 1996; p. 2064 -2065 .

14. Chowdhury D, Sayeed A, Shah A, Alam Bhuryar M, Mohal A, Khan GRM. Antimicrobial activity and cytotoxicity of Aerva lanata. Fitoterapia 2002; 73: 92-94.

15. Udupihille M, Jiffry MTM. Diuretic effect of Aerva lanata with water, normal saline and coriander as controls. Indian $J$ Physiol Pharmacol 1986; 30: 91-97.
16. Rao SG. Evaluation of an experimental model for studying urolithiasiss effect of Aerva lanata on urinary stones. Indian Drugs 1985; 22: 81-86.

17. Vetrichelvan T, Jegadeesan M, Senthil Palaniappan M, Murali NP, Sasikumar K. Diuretic and Anti-inflammatory activities of Aerva lanata in rats. Indian J pharma Sci 2000; 62: 300-302.

18. Zapesochnaya G. Canthin-6-one and beta-carboline alkaloids from Aerva lanata. Planta med 1992; 88: 192-196.

19. Rajesh R, Chitra M, Padmaa MP. Anti-hyperglycemic and antilipidemic activity of aerial part of Aerva lanata Linn. Juss. in streptozotocin induced diabetic rats. Asian Pac J Trop Biomed 2012; 2: S924-S929.

20. Marble A, Krall LP, Bradley RF, Christlieb AR, Soeldner JS, editors. Joslin's diabetes mellitus. 12th ed. Philadelphia: Lea-Febiger; 1985. p. 526-52.

21. Wheat LJ. Infection and diabetes mellitus. Diabetes Care. 1980; 3: 187-197.

22. Kates SG, Nordstrom KM, McGinley KJ, Leyden JJ. Microbial ecology of interdigital infections of toe web spaces. $J$ Am Acad Dermatol 1990; 22: 578-582.

23. Tekeli A, Dolapci I, Emral R, Cesur S. Candida carriage and Candida dubliniensis in oropharyngeal samples of type-1 diabetes mellitus patients. Mycoses 2004; 47: 315-8.

24. Vijayan Mini N, Da Barreto I, seema D, Shital D, Riva DS, Astrida R. Antimicrobial activity of ten common herbs, commonly known as Dashapudhpam from Kerala, India. Afr $J$ Microbiol Res 2010; 4: 2357-2362.

25. Parekh J, Nair R, Chanda S. Preliminary screening of some folklore medicinal plants from western India for potential antimicrobial activity. Indian J Pharmacol. 2005; 37: 408-409.

26. Perez C, Paul M, Bazerque P. Antibiotic assay by agar well diffusion method. Acta Biol Med Exp 1990; 15: 113-115.

27. CSIR. Wealth of India, publications and information directory, New Delhi, India: CSIR, 164:1998.

28. Portillo A, Vila R, Freixa B, Adzet $T$, Canigueral S. Antifungal activity of Paraguayan plants used in traditional medicine. J Ethnopharm 2001; 6:93-98.

29. Fortes TO, Alviano DS, Tupinamba G, Padron TS, Antoniolli AR, Alviano CS, et al. Production of an antimicrobial substance against Cryptococcus neoformans by Paenibacillus brasilensis $\mathrm{Sa} 3$ isolated from the rhizosphere of Kalanchoe brasiliensis. Microbiol Res 2008; 163:200-207.

30. Cowan MM. Plant products as antimicrobial agents. Clin microbiol rev 1999; 12: 564-82.

31. Arumugam N, Kandasamy $S$, Sekar M. In vitro antifungal activity of Hybanthus enneaspermus F Muell. Int J Pharm Pharm Sci 2012; 4: 594-596.

32. Basma AA, Zuraini Z, Sasidharan S. A transmission electron microscopy study of the diversity of Candida albicans cells induced by Euphorbia hirta L. leaf extract in vitro. Asian Pac J Trop Biomed 2011; 1(1): 20- 22.

33. Singariya $\mathrm{P}$, Kumar $\mathrm{P}$, Mourya KK. Estimation and bio activity of aerial parts of Withania somnifera against the bacterial and fungal microbes. Int J Pharm Pharm Sci 2012; 4: 553-557.

34. Kumar EAO, Rani DS. Studies on In vitro antimicrobial activity of some medicinal Plants from Visakhapatnam. Res $J$ Pharm Biol Chem Sci 2012; 3: 807.

35. Mathur A, Singh R, Yousuf S, Bhardwaj A, Verma S, Babu 
$\mathrm{P}$, et al. Antifungal activity of some plant extracts against clinical pathogens. Adv Appl Sci Res 2011; 2: 260-264.

36. Sule WF, Okonko IO, Joseph TA, Ojezele MO, Nwanze JC, Alli JA, et al. In vitro antifungal activity of Senna alata Linn. crude leaf extract. Adv Appl Sci Res 2010; 2:14-26.

37. Abera A, Lemessa F, Muleta D. The antifungal activity of some medicinal plants against coffee berry disease caused by Colletotrichum kahawae. Int J Agric res 2011; 3: 268-279.

38. Bohra NK, Purohit DK. Effect of some aqueous plant extracts on toxigenic strain of Aspergillus flavus. Adv Plant Sci 2002; 15: 103-106.

39. Polaquini SR, Svidziniski TI, Kemmelmeier C, Gasparetto A. Effect of aqueous extract from neem Azadirachta indica A. Juss on hydrophobicity, biofilm formation and adhesion in composite resin by Candida albicans. Arch Oral Biol 2006; 51: 482-490.

40. Taskeen UN, Wani AH, Mir RA. Antimycotic activity of plant extracts on the spore germination of some pathogenic fungi. Mycopath 2010; 8: 65-69.

41. Manohari R, Prasanna G. In vitro antioxidant and antimicrobial activities of Aerva lanata L. Ijppr Human. 2016; 6: 191-201.

42. Chowdhary D, Sayeed A, Islam A, Bhuiyan MSA, Astaq MKGR. Antimicrobial activity and cytotoxicity of Aerva lanata. Fitoterapia 2002; 73: 92-94.

43. Amutha K. Antimicrobial activity of Aerva lanata, Boerhavia diffusa, Cassia tora, Pongamia pinnata and influence on the virulence factors of multi-drug resistant Escherichia coli and Pseudomonas aeruginosa. U publish. info: 2010; p. 1.

44. Soundararajan $\mathrm{P}$, Mahesh $\mathrm{R}$, Ramesh $\mathrm{T}$, Hazeena BV. Biopotency of Aerva lanata on membrane bound ATPases and marker Enzymes in Urolithic Rats. Int J Biol Chem sci 2007; 1: 221-228.

45. Yamunadevi M, Wesely EG, Johnson M. Phyochemical studies on the trepenoids medicinally important plant Aerva lanata L. using HPTLC.Asian Pac J Trop Biomed 2011;1:22025. 46. Marjorie C. Plant products as antimicrobial agents. Clin Microbiol Rev 1999; 12: 564-582.

47. Hoult JRS, Paya M. Pharmacological and biochemical actions of simple coumarins: natural products with therapeutic potential. Gen Pharmacol 1996; 27: 713-722.

48. Zablotowicz RM, Hoagland RE Wagner SC. Effect of saponins on the growth and activity of rhizosphere bacteria. $A d v$ Exp Med Bio 1996; 405: 83-95.

49. Jamuna $S$, Paulsamy $S$, Karthika K. In vitro antibacterial activity of leaf and root extracts of Hypochaeris radicata L. (Asteraceae) - a medicinal plant species inhabiting the high hills of Nilgiris, the Western Ghats. Int J Pharm Pharm Sci 2013; 5: 175-178.

50. Zidon C, Schubert B, Stuppner H. Altitudinal differences in the contents of phenolics in flowering heads of three members of the tribe Lactuceae (Asteraceae) occurring as introduced species in New Zealand. Biochem Syst Ecol 2005; 33: 855-872. 51. Chen HM, Chan SC, Lee JC, Chang CC, Murugan M, Jack RJ. Transmission electron microscopic obse rvations of membrane effects of antibiotic cecropin B on Escherichia coli. Microsc Res Tech 2003; 62: 423-430.

52. Adetumbe M, Javor GT, Lau BH. Allium sativum (garlic) inhibits lipid synthesis by Candida albicans. Antimicrob Agents Chemother 1986; 30: 499-501.

\section{How to cite?}

Vidhya R, Udayakumar R. Antifungal efficacy of leaf, flower and root of Aerva lanata (Linn.) against selected fungal pathogens J Immunol Clin Microbiol 2017; 2(1):7-13.

DOI: http://dx.doi.org/10.5455/jicm.19.20161205

Submit your next manuscript to the JICM and take full advantage of:

- Convenient online submission,

- Thorough peer review, Fast Response,

- No charges,

- Immediate publication on acceptance,

- Inclusion in Scopemed and High quality indexes,

- Research which is freely available for redistribution of the worldwide literature

To submit your manuscript, click on http://www.jiacm.com

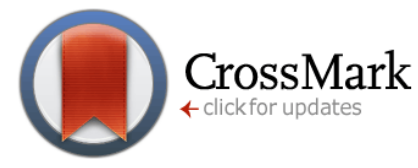

Published by The QMEL.org International Medical Education Library

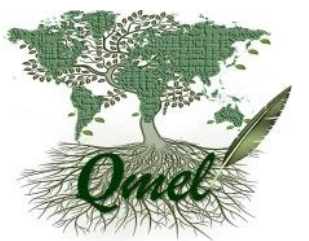

